\title{
First-Person Documentary Film and Self-Life Narration
}

Klaus Rieser, University of Graz

DOI: 10.47060/jaaas.v1i1.75

My contribution to this forum on life writing contemplates life narrative practices in documentary film and proposes two theses that also bear relevance for other fields and media under discussion here. Firstly, it problematizes the concepts of autobiography and life writing for their applicability to (documentary) film, arguing with Alisa Lebow for a notion of "first person film." Secondly, it contends that representations of the self in documentary film are more appropriately comprehended as a discourse rather than a genre.

In film, autobiography and biography are overlapping phenomena and, thus, hard to disentangle. For example, many documentaries which deliver an elaborate portrait of a filmmaker's self are actually studies of other persons, such as members of their family. This is the case in one of the most complex recent documentaries with an autobiographical aspect: Sarah Polley's Stories We Tell (2012). ${ }^{2}$ Based on interviews with siblings, friends, and relatives of her parents and (partly faux) home video footage, this film retraces her parents' relationship and her own discovery that she is the offspring of her mother's extramarital affair. In addition to being a family memoir, the film is also a clever contemplation of questions of truth, authenticity, memory, and identity. The film is not alone, however, in its circuitous rendering of subjectivity through a portrait of someone else "who informs the filmmaker's sense of him- or herself." " One may think, for example, of Michael Moore's oeuvre as an extended memoir, starting with Roger and Me (1989) and extending through most of his essayistic (rather than strictly autobiographical) films. In other words, such films are-at least partly-autobiographies in content but not in form.

Consequently, Lebow prefers the phrase "first person film" to "autobiographical film" because the films she analyzes speak from a particular, subjective position rather than being "about oneself": "[F]irst person film is not primarily, and certainly not always explicitly, autobiographical." She adds that "first person film" encompasses both the singular and the plural, both a "cinema of me" and "cinema of we," as these films overcome the subject/object dichotomy characteristic of traditional documentary film by constructing a dialogue between subjects. ${ }^{5}$ Thus, such films are characterized by "relationality," which Sidonie Smith and Julia Watson identify as one of three "enabling concepts" in life writing, the other two being "performativity" and "positionality." Moreover, this style of self-representation through a representation of close others, which Jim Lane labels "autobiographical portraiture," counters the reification of the individual subject, instead serving to "rupture the illusion of authenticity." This is precisely the case with Stories We Tell when the audience 
realizes that many of the seemingly authentic home video sequences in the film are actually scripted and acted.

This view of "autobiographical" films also corresponds with a concept of performativity prevalent in discourses about documentary film (as well as in life writing studies). For Bill Nichols, "performative" is one among six types of documentary film, characterized by being performed for the camera, and distinguished from expository, observational, participatory, reflexive, and poetic modes. ${ }^{9}$ In contrast, Stella Bruzzi asserts that "the performative documentary uses performance within a non-fiction context to draw attention to the impossibilities of authentic documentary representation." In this way, she wishes to expand the notion of performativity for documentary film, stressing "that documentaries are a negotiation between the filmmaker and reality, and, at heart, a performance."11 This assessment of contemporary documentary film in general is, in my view, particularly true for "first person film" because it is so frequently characterized by a performance of relationships. It also coincides with Smith and Watson's assessment that "self-life narration" (their term for autobiography) is defined more by what it does than by what it is. ${ }^{12}$

Performative and self-reflexive auto/biographical documentaries such as Stories We Tell also fit well into what John Corner identifies as "postdocumentary."13 On the one hand, critics such as Corner lament that by the 2000s, defining features of the classical documentary, such as a relation to democratic civics, a journalistic ethos, radical interrogation, and alternative positions, have given way to formats such as Reality TV-that is, to formats that are mostly characterized by diversion. On the other hand, the term "postdocumentary" (as in other cases of the use of "post") does not refer to a time after documentary, but rather to an opening up of possibilities: next to the classical documentary, the genre is now characterized by proliferating styles, revivals (of the classical monumental biopic, for example), and self-reflexive forms. Thus, we now encounter not only new forms of documentary "film" (from television docusoaps to action camera films) in diverse media (from the cinematic to online videos) which refer to a multiplicity of "realities" (from make-up tutorials to social commentary), but also an increase of autodocumentaries. In fact, auto/biographical documentary films have been booming in the twenty-first century, in digital media, social networks, video channels-and in cinemas. This is particularly striking because, before the 1980s, self-representation occurred much more rarely through the mode of documentary film. Since classical documentaries strove for "objectivity," a first-person address was generally relegated to marginalized formats such as avant-garde film (e.g. visionary film or diary film) and home movies. Since then, however, the personal and the political have been more commonly merged-still marginalized but forming a substantial body of works which engage the intersection of the autobiographical self, the questions of mediation, 


\section{0}

Nassim W. Balestrini et al.

and the relation to others. As Jim Lane states, "The autobiographical documentary sets in motion a paradoxical representational scheme in which the self and historical events are referenced at the same time that they are 'mediated."'/4

How can we, then, best capture the changing forms and salient features of contemporary auto/biographical documentary film alluded to in this cursory overview? For this purpose, it may be helpful to shift the analytical focus from genre and media to discourse (in a Foucauldian sense) since, as we have seen, first-person film is not easily contained within neither a particular genre nor a particular medium. Furthermore, the changes which auto/biographical film has undergone since the 1980 s may also be best understood as aspects of a larger social transformation, a paradigm shift between different discursive formations. It seems quite plausible that the transformation of the documentary, and in particular of the first-person documentary, coincides with an epistemic shift from a discourse of truth-telling to a discourse of self-revelation and self-invention with a corresponding new understanding of the subject of these films: rather than assuming a stable, self-contained individuality, these films offer examinations of subjectivities as transient, related, and narrative constructions.

\section{Notes}

1 Alisa Lebow, The Cinema of Me: The Self and Subjectivity in First Person Documentary (London: Wallflower Press, 2012).

2 Stories We Tell, dir. Sarah Polley (Toronto, ON: Mongrel Media, 2012).

3 Lebow, Cinema of Me, 1 .

4 Ibid., 2. This approach is related to Bill Nichols's claim that the defining aspect of documentary film is that of a particular "voice" composed of voice-over, dialogue, and technical choices (such as pans, zooms, etc.). In other words, for Nichols, the individual "voice" of the filmmaker is primary while the channelling of this voice through genre (autobiography, biography, etc.) is secondary. Bill Nichols, Introduction to Documentary (Bloomingdale: Indiana University Press, 2010).

5 Lebow, Cinema of Me, 3.

6 Sidonie Smith and Julia Watson, Reading Autobiography: A Guide for Interpreting Life-Narratives (Minneapolis: University of Minnesota Press, 2010), 214-6.

7 Jim Lane, The Autobiographical Documentary in America (Madison: University of Wisconsin Press, 2002), 94-143.

8 Lebow, Cinema of Me, 5.

9 Nichols, Introduction to Documentary.

10 Stella Bruzzi, New Documentary: A Critical Introduction (2000; London: Routledge, 2006), 185.

11 Ibid., 186. In a related move, Robert A. Rosenstone praised experimental historical film as early as 1995: "History as experiment does not make the same claim on us as does 


\section{3}

Forum: Life Writing and American Studies

the realist film. Rather than opening a window directly onto the past, it opens a window onto a different way of thinking about the past." Robert A. Rosenstone, "The Historical Film as Real History," Film-Historia 5, no. 1 (1995), http://revistes.ub.edu/index.php/filmhistoria/article/view/12244/14998.

12 Smith and Watson, Reading Autobiography, 19.

13 John Corner, "Performing the Real: Documentary Diversions," Television and New Media 3, no. 3 (2002): 257, https://doi.org/10.1177/152747640200300302.

14 Lane, Autobiographical Documentary, 192.

\section{Online Life Writing}

Silvia Schultermandl, University of Graz DOI: 10.47060/jaaas.viii.76

The advent of Facebook in 2004, Twitter in 2006, Tumblr in 2007, Instagram and Pinterest in 2010, and Snapchat and Google+ in 2011 facilitated the emergence of "everyday" autobiographies out of keeping with memoir practices of the past.' These "quick media" enable constant, instantaneous, and seemingly organic expressions of everyday lives. ${ }^{2}$ To read quick media as "autobiographical acts" allows us to analyze how people mobilize online media as representations of their lives and the lives of others. ${ }^{3}$ They do so through a wide range of topics including YouTube testimonials posted by asylum seekers and the life-style-oriented content on Pinterest. ${ }^{4}$ To be sure, the political content of these different quick-media life writing forms varies greatly. Nevertheless, in line with the feminist credo that the personal is political, these expressions of selfhood are indicative of specific societal and political contexts and thus contribute to the memoir boom long noticed on the literary market. ${ }^{5}$

Through this collapse of the boundaries between offline and online lives it becomes clear that quick media are sources of empowerment and vulnerability at the same time: notions of a democratic (easily accessible and affordable) usage coalesce with issues of user security and big data mining, on the one hand, and new social division along the infamous "digital divide" between internet-savvy users and those who lack the resources to participate in this form of online communication culture, ${ }^{6}$ on the other. And while in media studies the skepticism toward the quality of cyber-relationships produces interesting observations about the social use of social media, the field of life writing studies has witnessed a proliferation of new terminology which addresses the multi-medial and multi-modal shape given to online lives. For instance, the concept of "autobiographics" describes the practice of uploading visual content; similarly, the concept of "auto assemblages" references the layers of text generally featured on quick media that replace understanding of the verbal mediation of life narratives. ${ }^{8}$ Likewise, practices such as "auto/curating" point toward a form of autobiographical self-expression composed primarily 